University of Nebraska - Lincoln

DigitalCommons@University of Nebraska - Lincoln

$12-2016$

\title{
MODELING THE EFFECTS OF TILE DRAIN PLACEMENT ON THE HYDROLOGIC FUNCTION OF FARMED PRAIRIE WETLANDS1
}

\author{
Brett Werner \\ Centre College, Danville \\ John Tracy \\ Texas A\&M University, john.tracy@ag.tamu.edu \\ W. Carter Johnson \\ South Dakota State University \\ Richard A. Voldseth \\ North Dakota State University \\ Glenn R. Guntenspergen \\ United States Geological Survey
}

See next page for additional authors

Follow this and additional works at: https://digitalcommons.unl.edu/usgsstaffpub

Part of the Geology Commons, Oceanography and Atmospheric Sciences and Meteorology Commons, Other Earth Sciences Commons, and the Other Environmental Sciences Commons

Werner, Brett; Tracy, John; Johnson, W. Carter; Voldseth, Richard A.; Guntenspergen, Glenn R.; and Millett, Bruce, "MODELING THE EFFECTS OF TILE DRAIN PLACEMENT ON THE HYDROLOGIC FUNCTION OF FARMED PRAIRIE WETLANDS1" (2016). USGS Staff -- Published Research. 1156.

https://digitalcommons.unl.edu/usgsstaffpub/1156

This Article is brought to you for free and open access by the US Geological Survey at DigitalCommons@University of Nebraska - Lincoln. It has been accepted for inclusion in USGS Staff -- Published Research by an authorized administrator of DigitalCommons@University of Nebraska - Lincoln. 


\section{Authors}

Brett Werner, John Tracy, W. Carter Johnson, Richard A. Voldseth, Glenn R. Guntenspergen, and Bruce Millett

This article is available at DigitalCommons@University of Nebraska - Lincoln: https://digitalcommons.unl.edu/ usgsstaffpub/1156 


\title{
MODELING THE EFFECTS OF TILE DRAIN PLACEMENT ON THE HYDROLOGIC FUNCTION OF FARMED PRAIRIE WETLANDS ${ }^{1}$
}

\author{
Brett Werner, John Tracy, W. Carter Johnson, Richard A. Voldseth, Glenn R. Guntenspergen, and Bruce Millett ${ }^{2}$
}

\begin{abstract}
The early 2000s saw large increases in agricultural tile drainage in the eastern Dakotas of North America. Agricultural practices that drain wetlands directly are sometimes limited by wetland protection programs. Little is known about the impacts of tile drainage beyond the delineated boundaries of wetlands in upland catchments that may be in agricultural production. A series of experiments were conducted using the well-published model WETLANDSCAPE that revealed the potential for wetlands to have significantly shortened surface water inundation periods and lower mean depths when tile is placed in certain locations beyond the wetland boundary. Under the soil conditions found in agricultural areas of South Dakota in North America, wetland hydroperiod was found to be more sensitive to the depth that drain tile is installed relative to the bottom of the wetland basin than to distance-based setbacks. Because tile drainage can change the hydrologic conditions of wetlands, even when deployed in upland catchments, tile drainage plans should be evaluated more closely for the potential impacts they might have on the ecological services that these wetlands currently provide. Future research should investigate further how drainage impacts are affected by climate variability and change.
\end{abstract}

(KEY TERMS: prairie pothole wetlands; tile drain impacts; hydrologic modeling; farmed wetlands.)

Werner, Brett, John Tracy, W. Carter Johnson, Richard A. Voldseth, Glenn R. Guntenspergen, and Bruce Millett, 2016. Modeling the Effects of Tile Drain Placement on the Hydrologic Function of Farmed Prairie Wetlands. Journal of the American Water Resources Association (JAWRA) 52(6):1482-1492. DOI: 10.1111/1752-1688.12471

\section{INTRODUCTION}

Wetlands in the Prairie Pothole Region (PPR) of North America are well known for their importance to migratory waterfowl (Walker et al., 2013), shorebirds (Skagen et al., 2008), and amphibians (Lehtinen et al., 1999), and for flood mitigation, among other ecosystem services (Gleason et al., 2008). Despite the value of these wetlands to society, purposeful drainage of wetlands has occurred over the past century as grassland and associated wetlands have been converted into cropland. Wetland drainage was accomplished by the digging of surface ditches or by burying clay tile in farm fields that led from the wetland basin to an outlet into a stream, larger wetland or lake, road ditch, or large, open ditch (Prince, 1997).

While purposeful drainage of wetlands continues today, Farm Bill program participants must adhere to "Swampbuster" provisions in the Food Security Act of 1985 . However, in the early 2000s legal decisions

\footnotetext{
${ }^{1}$ Paper No. JAWRA-14-0236-P of the Journal of the American Water Resources Association (JAWRA). Received November 19, 2014; accepted August 22, 2016. (C) 2016 American Water Resources Association. Discussions are open until six months from issue publication.

${ }^{2}$ Assistant Professor (Werner), Environmental Studies, Centre College, Danville, Kentucky 40422; Director (Tracy), Texas Water Resources Institute, Texas A\&M University, 2260 TAMU, College Station, Texas 77843; Professor (Johnson), Department of Natural Resource Management and Assistant Professor (Millett), Department of Geography, South Dakota State University, Brookings, South Dakota 57007; Adjunct Assistant Professor (Voldseth), School of Natural Resource Sciences, North Dakota State University, Fargo, North Dakota 58108; and Research Ecologist (Guntenspergen), Patuxent Wildlife Research Center, United States Geological Survey, Laurel, Maryland 20708 (E-Mail/ Tracy: john.tracy@ag.tamu.edu).
} 
weakened some of the additional protection provided by the Clean Water Act (Van der Valk and Pederson, 2003). Johnston (2013) and Wright and Wimberly (2013) reported sharp increases in the rates of wetland and grassland conversion into cropland in the PPR in the past decade when grain commodity prices soared to record levels.

While increased rates of purposeful wetland drainage remain a concern to conservationists, a more recent concern has emerged over the increase in field tiling. More recently, a faster, more efficient, and cheaper method of tiling using plastic drainage pipe has become available. Because large numbers of wetlands are embedded in farmland that is being tile drained, they may be affected in diverse ways. If tile is placed too close to wetlands or too deep, wetlands may inadvertently be drained or their hydrologic regime and ecological function altered or impaired. Many of these wetlands in farmland are protected by conservation easements and other wetland protection programs administered by the United States Department of Agriculture Natural Resources Conservation Service (USDA NRCS) and the Department of Interior United States Fish and Wildlife Service (DOI USFWS). While many drainage projects in upland zones remain largely undocumented, landowners who pursue agricultural drainage near wetlands often must coordinate with appropriate agencies and these engagements have increased dramatically in recent years (Doherty et al., 2013).

North and South Dakota escaped large-scale installation of drainage tile until the early 2000 s. The reasons why large numbers of landowners have recently tiled their fields or are awaiting approvals are several and include: a wet climatic cycle (Werner et al., 2013), the ability of tile drainage to improve crop yield (Schwab et al., 1975; Kanwar et al., 1988), rising commodity prices (Leibtag, 2008; U.S. Department of Agriculture, 2014), and recent changes to federal policies regarding wetland protection (Van der Valk and Pederson, 2003).

Considerable uncertainty remains about the effects of tile drainage in the upland zones surrounding wetlands, and a degree of ambiguity remains at the interface of agricultural drainage and wetland protection. The USDA NRCS specifies particular setback distances for drainage plans around wetlands. The USDA standard of minimal impact is calculated using the groundwater regeneration potential and groundwater drawdown rate at the boundary of wetland and upland. Specifically, calculations are made to establish how close a drain can be to a wetland without lowering the water table more than $30 \mathrm{~cm}$ in the soil profile adjacent the wetland over certain time periods. While offering a modicum of consistency, this method of calculating setback distances does not explicitly address the impact of drainage on wetland surface water conditions and ecological function. Simply put, the topic of setback distances is a critically important issue at the science-policy interface that deserves more careful study and evaluation.

At present, no published field studies quantify the impacts of tile drainage installation on the surface water regime of wetlands within the PPR. Rather, field studies have focused primarily on the impact of tile drain systems on the soil-water conditions as they relate to the production of commodity crops (maize, soybeans), which offer little insight into the impacts of tile drain installations on wetland- and wildlife-specific indicators. Thus, to inform decision making at the interface between agricultural and wildlife interests, simulation-based analytic tools are needed. In situations where adequate field research is unavailable, limited, or difficult to obtain for financial and other practical reasons (e.g., length of study time necessary), simulation modeling offers an entry point for scientific study of complex system dynamics, such as those that exist in understanding the hydrology of prairie pothole wetland complexes. In this study, we adapted the WETLANDSCAPE (WLS) system dynamics model (Johnson et al., 2010; Werner et al., 2013) to conduct a series of experiments to estimate impact of tile drainage in upland catchments on the hydrologic function of prairie pothole wetlands of the eastern Dakotas of North America.

Prairie wetlands are hydrologically dynamic and ecologically diverse. Under average climate conditions most wetlands fill with water in spring and dry in summer to varying degrees, while wetter or drier climates yield deluges and droughts on multiyear intervals. These wet-dry dynamics maintain primary productivity while the early season inundation provides habitat for numerous organisms (amphibians, waterfowl, etc.) whose reproductive cycles depend on inundation periods of 70-130 days (Johnson et al., 2010). WLS simulates the period of inundation (hydroperiod) as a percentage of the ice-free season and the average depth of inundation of a wetland in meters over the ice-free season. These are two surface water metrics that offer direct insight into biological and ecological structure and function of wetland systems. A shortened hydroperiod or decreased mean water depth alters ecosystem services, including reductions in local aquifer recharge, altered primary productivity as a basis for food webs and trophic structure, lowered capacity to support plant biodiversity, altered resilience to invasive plant species, and reductions in densities of many invertebrates, amphibians, waterfowl, and other wetland-dependent species (Zedler, 2003; Zedler and Kercher, 2005). If 
agricultural tile drainage in the upland catchment shortens hydroperiod and decreases mean depth, then large-scale drainage in the eastern Dakotas may threaten to change the landscape-scale ecological patterns toward a drier landscape, whereby water has been directed downstream. Given the added stress that climate variability and change might place on prairie wetlands in the eastern Dakotas (Johnson et al., 2005, 2010), any added impacts such as drainage on wetland services deserve careful study and evaluation.

\section{ANALYTICAL APPROACH}

We used the WLS model to compute mean water depth and hydroperiod of a seasonal wetland basin (Stewart and Kantrud, 1978) with and without drain tiles in the upland catchment. This objective required having three main components: (a) an established wetland dynamics model amenable to modification to include tile drainage effects; (b) a wetland landscape typical of those farmed in this portion of the PPR; (c) a meteorological dataset representative of farmed land that had either been tiled or was a candidate for future tiling.

\section{Wetland Water Balance Model}

WLS was modified to include the effects of agricultural tile drainage. WLS was developed and refined over more than 20 years of research (Poiani and Johnson, 1993; Poiani et al., 1995, 1996; Johnson et al., 2004, 2005; Voldseth et al., 2007, 2009; Johnson et al., 2010; Werner et al., 2013). It uses the Stella $\odot$ modeling platform (ISEE Systems, Lebanon, New Hampshire) and is a process-based, deterministic wetland model originally constructed to address the effects of climate change and land cover on wetland dynamics. WLS simulates wetland surface water, groundwater, and vegetation dynamics (Figure 1). Primary model inputs include wetland bathymetry, watershed characteristics (slope, vegetation cover, soil properties), and climate (temperature and precipitation). In WLS, water enters the wetland as precipitation (ponded precipitation falls on the surface water zone; unponded precipitation falls on dry wetland area), surface runoff, and flux from groundwater following the chain of infiltration, percolation, and groundwater recharge. Water leaves the wetland through evapotranspiration, overflow, and flux to groundwater. At each time step, depths of surface water and local groundwater are calculated, and from these, surface water depthduration relationships are produced as output variables. Here, the WLS model was adapted to simulate a single basin using daily time steps and incorporating tile drainage simulation capabilities. Other equations and processes in WLS remain functionally unchanged from prior versions (Johnson et al., 2010; Werner et al., 2013). For ecological modeling, the wetland boundary was defined hydrologically as the maximal extent of surface water over a 43-year period simulation, a delineation corresponding to the wetland boundary set by the spill point. The United States Army Corps of Engineers uses a three-factor approach (hydrology, hydrophytes, and hydric soils) to determine jurisdictional wetland area and delineate the boundary between jurisdictional wetland and upland (Environmental Laboratory, 1987). This regulatory approach to jurisdictional wetland boundary determination is not well suited to defining the wetland boundary parameter in our modeling study because such jurisdictional boundaries are not static (fixed) in the landscape. For this study, the hydrologic boundary described above remains the most appropriate to yield meaningful results.

Simulation of Impacts of Tile Drains on Wetland System Fluxes. Several studies have estimated the impact of tile drain placement on the hydrology of cropland in landscapes containing wetlands (Luthin and Worstell, 1957; Toksoz and Kirkham, 1961; Van Schilfgaarde, 1963). Within the PPR, the USDA NRCS has utilized a methodology based on the Van Schilfgaarde equation (1963) to estimate the lateral effect on drawdown of the groundwater and to provide a uniform approach for calculating the minimum tile drain setback distances near wetlands. The general methodology for using the Van Schilfgaarde equation in determining these setback distances can be found in Jacobsen and Skaggs (1997), with key factors that are used to estimate the setback distance being: (1) soil characteristics; (2) depth of the drain below the water surface elevation in the wetland $=d-s$, where $d$ is the depth of the tile drain below the top of the wetland and $s$ is the distance between the top of the wetland and the water surface elevation in the wetland (variable over time); and (3) the time period for determining the allowable drawdown of water (Figure 2). The tile drain setback distance is then adjusted based on a number of additional site-specific factors, including: (1) the land slope; (2) whether the tile drains encircle the wetlands; and (3) whether surface inlets exist.

While the Van Schilfgaarde equation has been found to accurately predict the drawdown of a water 


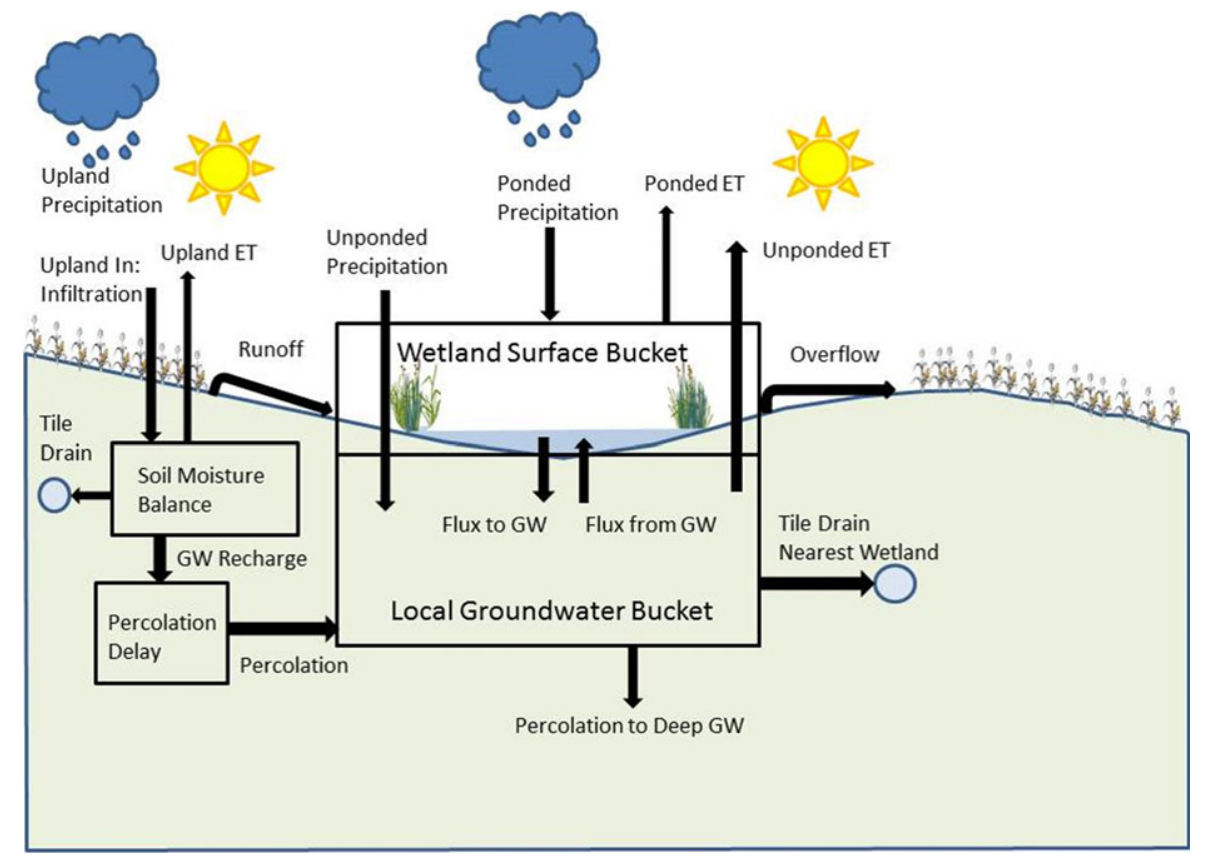

FIGURE 1. Schematic Diagram of WETLANDSCAPE Wetland Water Budget Including the Impacts of Tile Drains (modified from Johnson et al., 2010).

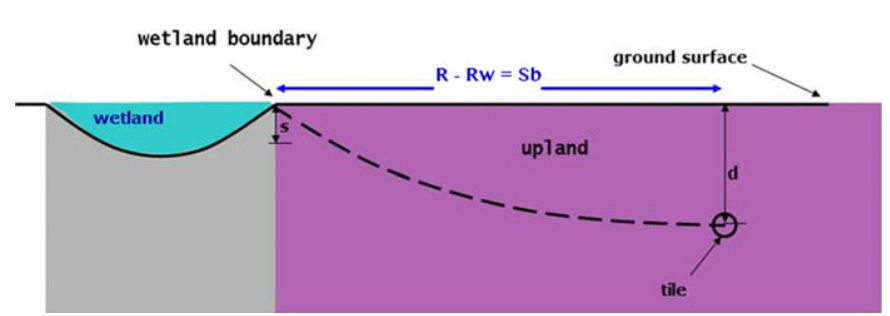

FIGURE 2. Schematic Diagram of the Generalized United States Department of Agriculture-Adopted Approach to Determine the Placement of Tile Drains near Wetlands Where $d$ Is the Depth of the Tile Drain below the Top of the Wetland, $s$ Is the Distance between the Top of the Wetland and the Water Surface Elevation in the Wetland (variable over time), and $S_{\mathrm{b}}$ Is the Distance of the Nearest Tile Drain to the Wetland Boundary.

table under the influence of tile drains (Johnston et al., 1965), the equation explicitly assumes that the drawdown of the water table is between two linear and parallel drainage or recharge features. This is often not the case when tile drains are placed near a wetland, where often the tile drains nearly encircle the wetland, as opposed to running parallel to the wetland. Thus, for use in simulating how the placement of tile drains will impact the water flux within a wetland system, we modified the Van Schilfgaarde equation to account for radial flow from the wetland to the tile drain that encircles the wetland (Figure 3).

Based on the Van Schilfgaarde equation, the instantaneous drainage rate, $i\left(\mathrm{~m}^{3} /\right.$ day $\left./ \mathrm{m}^{2}\right)$, for a field

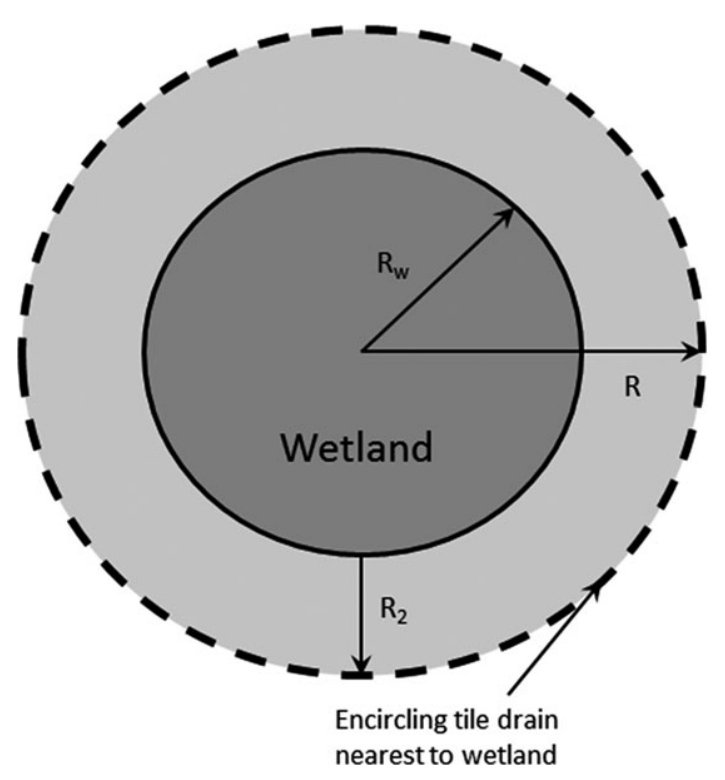

FIGURE 3. Schematic Diagram of the Placement of Tile Drains Encircling a Prairie Pothole Wetland.

being drained by tile drains that are parallel to each other can be expressed as:

$$
i=\frac{4 K m\left(m+2 d_{\mathrm{e}}\right)}{S_{\mathrm{b}}^{2}}
$$

where $K$ is the lateral hydraulic conductivity of the soil $(\mathrm{m} /$ day $) ; m$ is the elevation in the water table 
above the tile drains at the start of the simulation time period $(\mathrm{m})$.

$$
S_{\mathrm{b}}=\frac{S}{2}
$$

where $S$ is the spacing between tile drains (m); and $d_{\mathrm{e}}$ is the effective depth from the tile drain to an underlying impermeable layer.

The flux of water along a single tile drain can thus be derived by multiplying the instantaneous drainage rate by $S_{\mathrm{b}}$, such that:

$$
q=i \times S_{\mathrm{b}}=\frac{4 K m\left(m+2 d_{\mathrm{e}}\right)}{2 S_{\mathrm{b}}}
$$

where $q$ is the flux of water into the tile drain per unit length of tile drain $\left(\mathrm{m}^{3} / \mathrm{day} / \mathrm{m}\right)$.

However, to utilize the Van Schilfgaarde equation in determining the flux of water from a wetland to drainage tiles that encircle the wetland, it must first be converted into radial coordinates, which yields:

$$
q=\frac{K \pi D d_{\mathrm{e}}}{2 \pi R \ln \left(R / R_{\mathrm{w}}\right)},
$$

where $q$ is the flux of water into the tile drain encircling the wetland per unit length of drain $\left(\mathrm{m}^{3} /\right.$ day $\left./ \mathrm{m}\right)$; $K$ is the lateral hydraulic conductivity of the soil ( $\mathrm{m} /$ day); $D$ is the depth of the water table in the hydric zone above the bottom of the tile drain $(\mathrm{m}) ; R$ is the effective radial distance from the center of the wetland to the nearest tile drain $(\mathrm{m})$ as shown in Figure 3 ; and $R_{\mathrm{w}}$ is the approximate radius of the wetland $(\mathrm{m})$, calculated as $=\sqrt{A / \pi}$; where $A$ is the surface area of the wetland $\left(\mathrm{m}^{2}\right)$.

As noted in Van der Kamp and Hayashi (2009), the hydraulic conductivity of soils within prairie pothole watersheds can vary widely. Van der Kamp and Hayashi (2009) summarized the results of previous studies (Hayashi et al., 1998; Van der Kamp et al., 2003; Parsons et al., 2004), demonstrating that the hydraulic conductivity of soils tends to decrease with depth beneath the land surface, with hydraulic conductivities generally being in the range of $3 \times 10^{-6}$ to $3 \times 10^{-4} \mathrm{~m} /$ day at depths greater than $4 \mathrm{~m}$ below the ground surface. For soils within 1-2 $\mathrm{m}$ of the ground surface, they found that hydraulic conductivities typically range from a low of $1 \times 10^{-3} \mathrm{~m} /$ day to values over $20 \mathrm{~m} /$ day very near the ground surface, with the average hydraulic conductivities estimated (using ring infiltrometer tests) to be approximately $0.3 \mathrm{~m} /$ day for soil beneath cultivated fields and $5 \mathrm{~m} /$ day for soil beneath grasslands. To arrive at these results required extensive field studies using ring infiltrometer tests, and the extraction of soil cores to run laboratory permeameter tests. Thus, it would be cost and time prohibitive to attempt to characterize the hydraulic conductivity of soils for each wetland where tile drainage is being considered for use. Thus, within the WLS model, the hydraulic conductivity is represented as a lumped parameter, where the weighted arithmetic mean of the variation in the hydraulic conductivity in space and time is assumed to adequately represent the effective hydraulic conductivity beneath the wetland watershed for use in Equation (3). As the typical installation of tile drains occurs within $1.5 \mathrm{~m}$ of the ground surface, it is assumed that an appropriate range of average hydraulic conductivities would be between 1 and $10 \mathrm{~m} /$ day, although a much wider range of hydraulic conductivities will be used to test the sensitivity of model results to this parameter.

For radial flow, the effective depth from the tile drain to an underlying impermeable layer can be approximated as (Van der Molen and Wesseling, 1991):

$$
d_{\mathrm{e}}=\frac{\pi\left(\frac{2 R_{2}}{8}\right)}{\left[\ln \left(\frac{2 R_{2}}{\pi r_{0}}\right)+\mathrm{F}_{x}\right]},
$$

where $R_{2}$ is $R-R_{\mathrm{w}}$, which is the average distance of the encircling tile drain to the edge of the wetland (see Figure 3$) ; r_{0}$ is the radius of the tile drain $(\mathrm{m})$; and $\mathrm{F}_{x}$ is an infinite series which is a function of $x$, calculated as:

$$
\mathrm{F}_{x}=\sum_{i=0}^{\infty} 4 \frac{\mathrm{e}^{-2 x(2 i+1)}}{(2 i+1) \mathrm{e}^{-2 x(2 i+1)}},
$$

where:

$$
x=2 \pi \frac{D}{2 R_{2}}
$$

For each time step during the model simulation, the total flux of water removed by the tile drain nearest the wetland can then be calculated as:

$$
Q=2 q \pi R
$$

For tile drains placed in the upland portion of the wetland drainage basin, the flux of water drained by these tile drains is calculated as zero if the groundwater level in the upland zone is less than the elevation in the tile drains. If the groundwater level in the upland zone is greater than the elevation of the tile drains, the water flux due to tile drains is determined as the lesser value of the available recharge to the upland groundwater system, or the maximum 
drainage capacity of the tile system, as determined using Equation (1) multiplied by the effective area of the wetland basin that includes tile drains, such that:

$$
Q_{\mathrm{u}}=\frac{4 K m\left(m+2 d_{\mathrm{e}}\right)}{S_{\mathrm{b}}^{2}}\left(A_{\mathrm{w}}-\pi R_{2}^{2}\right)
$$

where $Q_{\mathrm{u}}$ is the flux of groundwater to tile drains in the upland wetland basin $\left(\mathrm{m}^{3} /\right.$ day); and $A_{\mathrm{w}}$ is the effective area of the wetland basin that includes tile drains $\left(\mathrm{m}^{2}\right)$.

The WLS model was modified to account for the additional water fluxes due to a tile drain encircling the wetland (Equation 6) and due to tile drains placed in the upland portion of the wetland basin (Equation 7). For all tile drainage model experiments, the tile drain diameter used was $12.7 \mathrm{~cm}$ (5 in.).

\section{Model Wetland Basin}

In prior research, WLS simulated wetlands at field research stations, including those of longer and shorter permanence types: temporary, seasonal, and semi-permanent (Johnson et al., 2010; Werner et al., 2013). Those studies calibrated and validated WLS using 18 years of observation data, which included both dynamic wetland water surface elevations and groundwater levels at the Orchid Meadows field research site (Figure 4 inset) for 10 monitored wetlands (3 temporary, 3 seasonal, and 4 semi-permanent). The WLS model provides a good representation of the dynamics of the wetlands' water surface levels over the 18-year simulation period for seasonal wetland basins (Figure 5A). However, at the current time there are no data available from field studies in the PPR where tile drain systems have been installed near wetlands. Simulations of the impacts of tile drain installation at the Orchid Meadow site could be performed using the modified WLS model. However, the steeply sloping topography of the Orchid Meadows study site makes it less typical of farmed wetland basins in the PPR. Thus, the results of simulating the impacts of tile drain installation at the Orchid Meadows site could not be extrapolated directly to the farmed regions within the PPR. Instead, for this study we chose to simulate the impacts of tile drain installation on the hydrologic behavior of a seasonal wetland (DF4S) at the Dailey Farm site (Figure 4) where the basin shape, soils, and catchment size are more typical of hydrologic conditions that exist for farmed areas of the PPR. The Dailey Farm study site was comprised of a large number of wetlands on relatively mildly sloping lands. Over its 11-year observational record (2000-2010), the Dailey Farm typically produced row crops (corn and soybean) with alfalfa and wheat produced less often. In addition, some fields were fallowed when flooded in wet years. Overall, the Dailey Farm study site is representative of the type of farm where tile drains could be installed

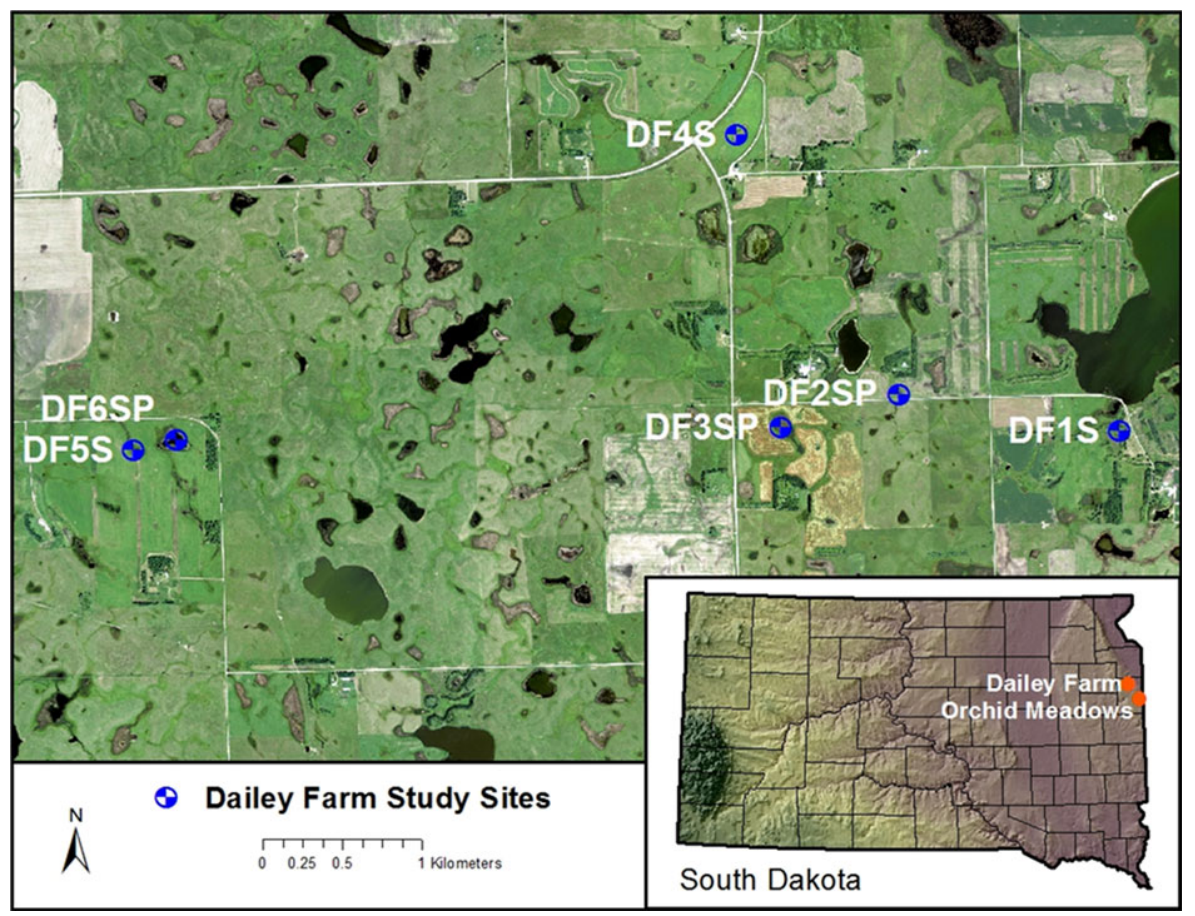

FIGURE 4. Landscape View of the Wetland Complex at the Dailey Farm Study Site. The Orchid Meadows study site can be seen in Figure S1. The Dailey Farm site is in a more agricultural matrix. The DF4S wetland was used in the tiling simulations. 


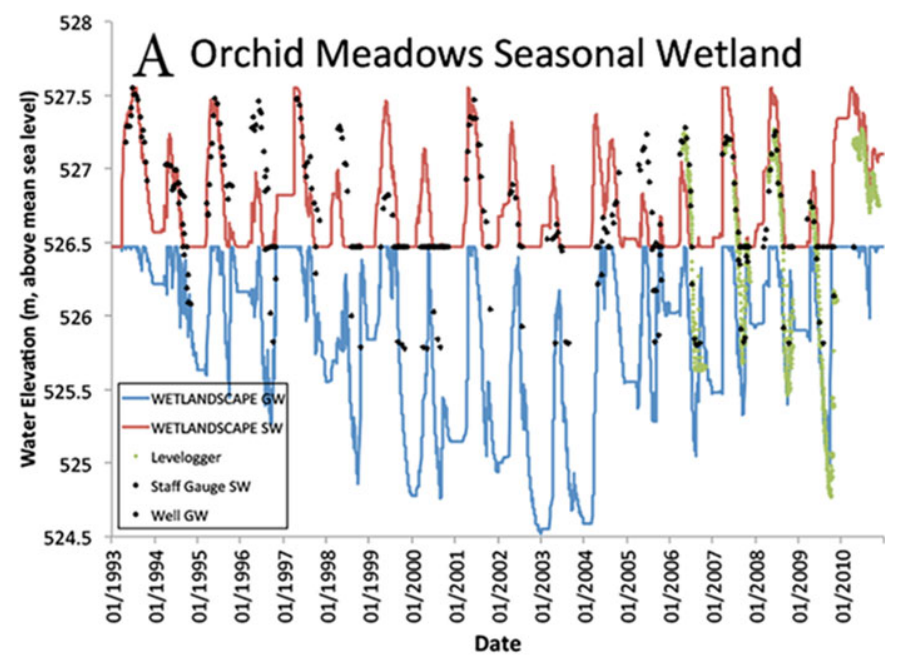

Dailey Farm Seasonal Wetland

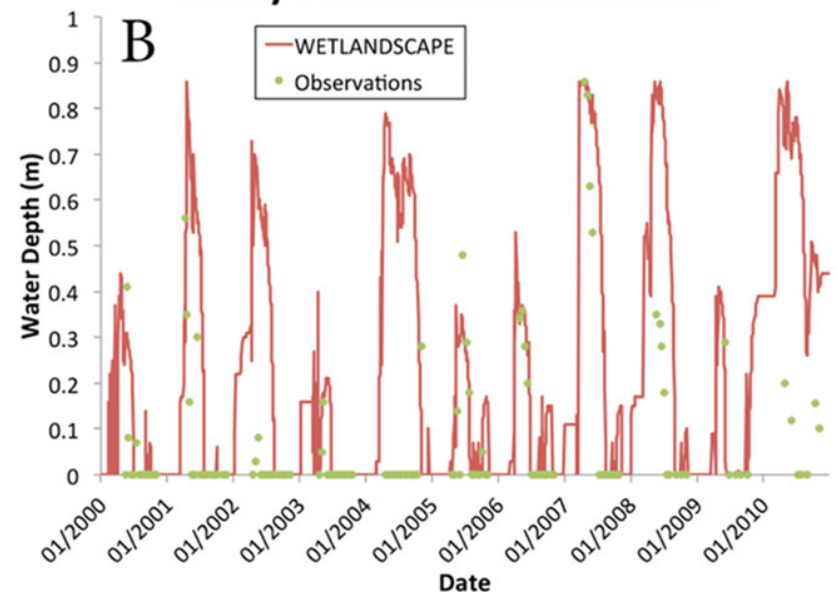

FIGURE 5. Calibration Simulations Show Observed Water Depths and WETLANDSCAPE Simulation Depths for One Basin from the More Rugged Prairie Coteau and One from a More Agricultural (flatter) Landscape and Bathymetry. The upper panel shows a seasonal basin (Orchid Meadows S3) with staff gage, well, and levelogger observations of surface water and groundwater levels. The lower panel shows DF4S seasonal basin.

to improve the yield and, hence the economic viability, of a corn-soybean crop rotation.

The DF4S wetland represented a typical situation where tile drains would be placed low in the topography and often near wetlands to enhance crop production. Upland soils surrounding this wetland were predominately of clay loam texture. The average slope of the wetland catchment was approximately $2 \%$, the wetland spill point was $0.55 \mathrm{~m}$ above the bottom of the wetland, the wetland area was $6,368 \mathrm{~m}^{2}$ at the spillway elevation, and the drainage area for the wetland was $44,000 \mathrm{~m}^{2}$. We had previously recorded water levels at the Dailey Farm wetlands using staff gage observations on 2-week intervals during the ice-free season for an 11-year period (2000-2010).

\section{Model Parameterization and Utilization Using Brookings, South Dakota Climate Data}

We parameterized the model using geospatial (slope, basin size, basin morphometry) and soil characteristics and increased the seepage rate of groundwater from shallow to deeper pools to address the larger catchment size of the mild sloping terrain. We simulated surface water levels using an 18-year meteorological dataset from Clear Lake, South Dakota (1993-2010: 16 km south of Dailey Farm) and compared the simulated results to the Dailey Farm field observation data (2000-2010). The WLS model simulated key water level dynamics including the spring rise and summer drawdown periods that drive the environmental conditions and organismic composition and their dynamics (Figure 5B).

After completing initial testing and parameterization of the model using the Clear Lake meteorological dataset, we ran experiments to investigate the sensitivity of the model to some hydrologic variables. As noted earlier, previous studies have indicated that the hydraulic conductivity can vary significantly within prairie pothole watersheds, and it is a variable that directly affects the lateral flow rate of water between a wetland and drainage tile. As this is a physical parameter, which cannot easily be altered through management practices, the impact of its variability in relation to a wetlands hydroperiod must be understood in relation to the placement of tile drains near wetlands. To test the sensitivity of predictions of the wetlands hydroperiod to changes in hydraulic conductivity, we fixed the tile drain depth within the watershed at $0.33 \mathrm{~m}$ below the wetland bottom and ran 40 simulations with setback distances from 10 to $160 \mathrm{~m}$ in $50 \mathrm{~m}$ increments, using conductivity values ranging from 0.0001 to $15 \mathrm{~m} /$ day. This range encapsulates hydraulic conductivity values typically found in agricultural soils in this area of the PPR, which are shown in Table 1.

TABLE 1. Range of Hydrologic Parameters Used in Sensitivity Analysis.

\begin{tabular}{lcccc}
\hline & Hydraulic Conductivity $(\mathbf{m} /$ day) & Slope $(\mathbf{m} / \mathbf{m})$ & Field Capacity $(\mathbf{d i m})$ & Permanence Type \\
\hline Modeled value & 7.7 & 0.02 & 0.345 & Seasonal \\
Tested range & $0.0001-15$ & $0.01-0.05$ & $0.25-0.4$ & Temporary, seasonal, semi-permanent \\
Field range & $7.7-11$ & $0.015-0.05$ & $0.332-0.345$ & Temporary, seasonal \\
\hline
\end{tabular}


Model simulations were then performed using meteorological data from the Brookings, South Dakota weather station for a 43-year period (19682010). The behavior of the baseline case in both the Clear Lake 18-year dataset and the Brookings 43year data matches well with established patterns of wetland dynamics from previous studies (Johnson et al., 2010). We chose the Brookings meteorological dataset in eastern South Dakota because the longer time interval offers a clearer signal-to-noise ratio in a climate that is quite variable. In addition, the Brookings region has already seen and remains likely to experience additional tile drainage expansion and could present opportunities for future testing.

To investigate the sensitivity of wetland hydroperiod to hydraulic conductivity and setback distance, we performed 40 model runs with a fixed tile depth of $0.33 \mathrm{~m}$ below wetland bottom. To investigate the effects of tile depth and setback distance on wetland hydroperiod and surface water depth, we performed 132 model runs using the Brookings meteorological data. We tested vertical placement depths ranging from $0.5 \mathrm{~m}$ above the bottom of the wetland to $1.33 \mathrm{~m}$ below the bottom of the wetland in $0.17 \mathrm{~m}$ increments, and horizontal placements of the tile drain from 1 to $200 \mathrm{~m}$ from the wetland boundary in $20 \mathrm{~m}$ increments. In practice, the placement of tile drains (depth and setback distance) is dictated by a number of site-specific factors, which includes the slope of the wetland basin, soil types, climate, and whether the wetland is part of a conservation program. The range of tile drain placement we tested using WLS includes the range of practices anticipated in the PPR. Wetland and drainage parameters (hydraulic conductivity, slope, field capacity, and wetland type) that were investigated for sensitivity are summarized in Table 1, with these variables being fixed for the testing of wetland hydrologic response to changes in tile drain placement.

\section{RESULTS AND DISCUSSION}

The wetland hydroperiod and mean water depth in WLS responded to changes in the depth and distance of tile placement from the wetland, and the hydraulic conductivity of the soil. These variables combined to yield a complex response to scenarios involving the installation of tile drains. Initial sensitivity testing showed that for sandier soils within a range of agricultural conditions (Table 1), drainage tiles that were placed closer to the wetland $(\sim 10 \mathrm{~m})$ that had higher soil conductivities (7-15 m/day) significantly shortened the hydroperiod (10-40\%) when tile drains were placed below the wetland bottom by $0.33 \mathrm{~m}$ or greater (Figure 6). This sensitivity analysis also indicates that the predicted changes in the hydroperiod of a wetland are relatively insensitive to changes in hydraulic conductivity for tiles that are placed further than $60 \mathrm{~m}$ from the wetland boundary, and at depths less than $0.33 \mathrm{~m}$ below the bottom of the wetland. Thus, when drains are placed closer to the wetland $(<50 \mathrm{~m})$ and at depths greater than $0.33 \mathrm{~m}$, accurately estimating the hydraulic conductivity of the soil will be important to be able to predict changes in a wetland's hydroperiod.

The baseline (without tile) hydroperiod for the Brookings meteorological data was 58.7\% ( 120 days), and the mean water depth was $0.24 \mathrm{~m}$. Simulations indicate that there are negligible effects on the hydroperiod and mean water depth when tile drains are placed greater than $200 \mathrm{~m}$ from the wetland boundary at a depth greater than $0.5 \mathrm{~m}$ above the bottom of the wetland. Placing tile drains closer than $200 \mathrm{~m}$ to the wetland and deeper than the $0.5 \mathrm{~m}$ depth above the bottom of the wetland resulted in shortened hydroperiods and decreased mean water depths, with deeper drains invariably shortening the wetland's hydroperiod, even at distances of $120 \mathrm{~m}$ or more (Figure 7).

Other simulations suggest that the hydroperiod would decrease from approximately $59 \%$ to less than $25 \%$ for the most extreme tile placements. At one extreme, tile placement in WLS at $1 \mathrm{~m}$ beyond the wetland boundary and $1.33 \mathrm{~m}$ below the bottom of the wetland produced a hydroperiod of approximately $25 \%$ ( $\sim 50$ days). At the other extreme, tile placement at $0.5 \mathrm{~m}$ above the wetland bottom resulted in the hydroperiod remaining at or near the baseline case (59\%) for any distances greater than $140 \mathrm{~m}$.

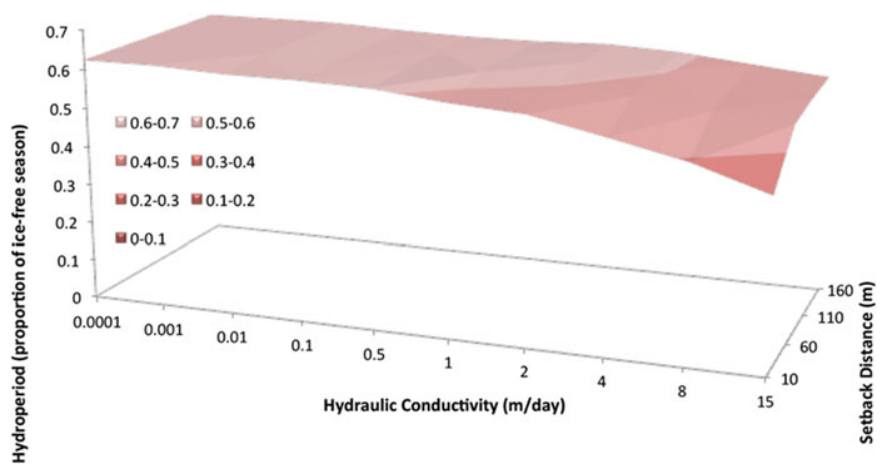

FIGURE 6. The Sensitivity Testing Combination of Tile Setback Distance and Hydraulic Conductivity Shows Hydroperiod Response to Higher Conductivity and Closer Setback Distances at $0.33 \mathrm{~m}$ below the Bottom of the Wetland. 


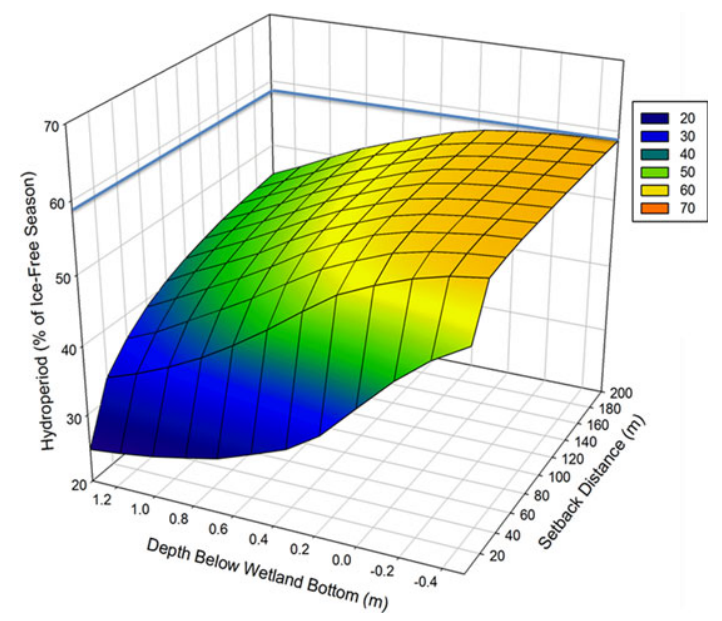

FIGURE 7. Hydroperiod vs. Tile Drain Setback Distance from the Wetland Boundary and Tile Drain Depth below the Bottom of the Wetland. The blue lines show the baseline (no tile) hydroperiod.

The mean depth of water surface in the wetland showed responses similar to those of the hydroperiod in response to changes in the horizontal and vertical placement of the tile drain (Figure 8). The mean water depth decreased by over $60 \%$ (from $0.24 \mathrm{~m}$ to less than $0.09 \mathrm{~m}$ ) for the most extreme tile drain placements $(1.33 \mathrm{~m}$ deep, $1 \mathrm{~m}$ from the wetland boundary). However, a mean water depth of $0.24 \mathrm{~m}$ (as in the baseline case) could be maintained for tile depths of $0.5 \mathrm{~m}$ above the wetland bottom when drains were as close as $80 \mathrm{~m}$. This wetland basin had a mean depth of $0.23 \mathrm{~m}$ even with tile drains at $0.17 \mathrm{~m}$ below the wetland bottom as long as the setback distance was $200 \mathrm{~m}$. Alternatively, a drain at the bottom of the wetland $(0.0 \mathrm{~m}$ tile depth) with an $80 \mathrm{~m}$ setback could have a similar mean water depth of $0.23 \mathrm{~m}$ (Figure 8A). As expected, the mean water depth decreased as the tile drain was placed closer to the wetland boundary, with a more pronounced decrease when the tile drain was placed within $20 \mathrm{~m}$ of the wetland. Using a fixed $20 \mathrm{~m}$ setback distance, mean depth decreased linearly relative to the depth of the tile drain, ranging from a high of $0.24 \mathrm{~m}$ (same as the baseline case) with a drain placement of $0.5 \mathrm{~m}$ above the bottom of the wetland to a low of $0.12 \mathrm{~m}$ with a drain placement of $1.33 \mathrm{~m}$ below the bottom of the wetland (Figure 8B).

These model experiments show that wetlands are sensitive to tile placement. The effects of placing tile drains, especially at any depth below the bottom of the wetland, could change the hydrologic behavior of the wetland. In extreme tile drainage placements (in terms of the distance-depth relationship), these effects could presumably transform the hydrological conditions of a wetland from that of a seasonal $(\sim 50 \%$ hydroperiod, or $\sim 100$ days) to that of a temporary
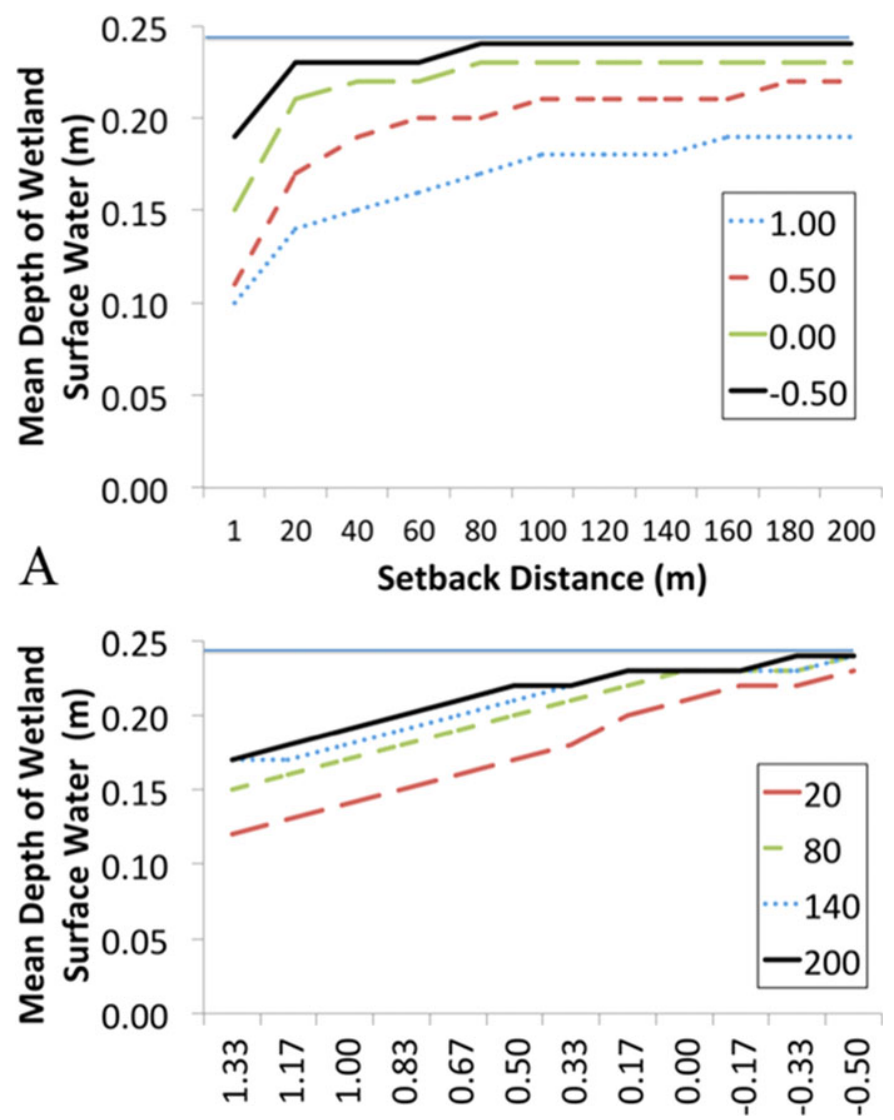

B

\section{Depth of Tile Drain Relative to Wetland Bottom (m)}

FIGURE 8. Mean Water Depth vs. (A) Tile Drain Set Back Distance from the Wetland Boundary and (B) vs. Tile Drain Depth below the Bottom of the Wetland. The black lines show the baseline (no tile) hydroperiod. In (A), the line types shown in the figure legend are the depths $(\mathrm{m})$ of tile below the bottom of the wetland. In (B), the line types shown in the figure legend are the setback distances $(\mathrm{m})$ beyond the wetland boundary.

wetland ( $<30 \%$ hydroperiod, or $<60$ days). This reduction in both the hydroperiod and mean depth would significantly affect ecological function of such basins, limiting the potential for waterfowl or amphibians to complete reproductive cycles and likely changing the composition of vegetation and macroinvertebrate communities (Van der Valk, 2012).

\section{SUMMARY AND CONCLUSIONS}

The WLS tool was modified to simulate the impact of tile drains on the hydrological functioning of farmed-around wetlands in part of the PPR. Simulations indicate that the placement of tile drains within the wetland watershed could significantly affect 
hydrologic function (hydroperiod, mean depth), and thereby the ecological services provided by these wetlands.

This study found that the most important component of tile placement to hydrologic functioning of wetlands was the elevation in the tile drain relative to the bottom of the wetland. Placement of tile drains below the bottom of wetlands more rapidly reduced water levels and thereby changed hydroperiod: in other words, fewer years would have the necessary 70-130 days of standing water that many wetland organisms need to complete their life cycles. In addition, the installation of tile drains within a wetland catchment reduced the mean depth of a wetland with the potential to cause a shift from a more permanent wetland type (e.g., seasonal) to a less permanent wetland (e.g., temporary). As yet, there are no field data available to evaluate these simulations. However, the model behavior captured the well-known components of the hydrologic regime of prairie wetlands, such as the spring rise, summer drawdown, and high interannual variability in hydroperiod.

Finally, studies are needed to evaluate how well model simulations match with field data from wetlands in tiled farmland. Because of the versatility of the modeling platform and approach, WLS has the potential to be an important tool to investigate the role of climate, wetland morphometry, and soils at the interface among wetlands, agriculture, and tile drainage. Future research should focus on how climate variability and change will affect the response of wetlands to the installation of tile drains.

\section{SUPPORTING INFORMATION}

Additional supporting information may be found online under the Supporting Information tab for this article: Supplemental Figure 1 provides a landscape view of the Orchid Meadows study site used in the development of the WETLANDSCAPE (WLS) model.

\section{ACKNOWLEDGMENTS}

This research was supported through a cooperative agreement and grant from the United States Fish and Wildlife Service Inventory and Monitoring Program and the United States Geological Survey Science Support Program, Grant and Cooperative Agreement No. G12AC20005. We also acknowledge support from the U.S. Geological Survey's Climate and Land-Use Research and Development Program and the Ecosystem Program. Any use of trade product or firm names is for descriptive purposes only and does not imply endorsement by the U.S. Government.

\section{LITERATURE CITED}

Doherty, K.E., A.J. Ryba, C.L. Stemler, N.D. Niemuth, and W.A. Meeks, 2013. Conservation Planning in an Era of Change: State of the U.S. Prairie Pothole Region. Wildlife Society Bulletin 37 (3):546-563, DOI: $10.1002 / \mathrm{wsb} .284$

Environmental Laboratory, 1987. Corps of Engineers Wetland Delineation Manual, Technical Report Y-87-1, U.S. Army Engineers Waterways Experiment Station, Vicksburg, Mississippi.

Gleason, R.A., M.K. Laubhan, B.A. Tangen, and K.E. Kermes, 2008. Ecosystem Services Derived from Wetland Conservation Practices in the United States Prairie Pothole Region with an Emphasis on the U.S. Department of Agriculture Conservation Reserve and Wetland Reserve Programs. U.S. Geological Professional Paper 1745, USGS Northern Prairie Wildlife Research Center, Washington, D.C.

Hayashi, M., G. van der Kamp, and D.L. Rudolph, 1998. Mass Transfer Processes between a Prairie Pothole and Adjacent Uplands, 1: Water Balance. Journal of Hydrology 207:42-55.

Jacobsen, S.M.M. and R. Skaggs, 1997. Lateral Effect: What's Known and Unknown. Proceedings for the 1997 ASAE Annual International Meeting. Paper No: 972034. Minneapolis, Minnesota, August 10-14, 1997.

Johnson, W.C., S.E. Boettcher, K.A. Poiani, and G. Guntenspergen, 2004. Influence of Weather Extremes on the Hydrology of Glaciated Prairie Wetlands. Wetlands 24:385-398.

Johnson, W.C., B.V. Millett, T. Gilmanov, R.A. Voldseth, G.R. Guntenspergen, and D.E. Naugle, 2005. Vulnerability of Northern Prairie Wetlands to Climate Change. BioScience 55 (10):863-872.

Johnson, W.C., B.A. Werner, G.R. Guntenspergen, R.A. Voldseth, B. Millett, D.E. Naugle, M. Tulbure, R.W.H. Carroll, J. Tracy, and C. Olawsky, 2010. Prairie Wetland Complexes As Landscape Functional Units in a Changing Climate. BioScience 60 (1):128-140.

Johnston, C.A., 2013. Wetland Losses Due to Row Crop Expansion in the Dakota Prairie Pothole Region. Wetlands 33:175-182, DOI: $10.1007 / \mathrm{s} 13157-012-0365-\mathrm{x}$.

Johnston, W.R., J. Letey, and A.F. Pillsbury, 1965. Tile Drainage Performance Compared to Theoretical Predictions. Transactions of the ASAE 8(4):0548-0549.

Kanwar, R.S., J.L. Baker, and S. Muhktar, 1988. Excessive Soil Water Effects at Various Stages of Development on the Growth and Yield of Corn. Transactions of the ASAE 31:133-141.

Lehtinen, R.M., S.M. Galatowitsch, and J.R. Tester, 1999. Consequences of Habitat Loss and Fragmentation for Wetland Amphibian Assemblages. Wetlands 19(1):1-12.

Leibtag, E., 2008. Corn Prices Near Record High, But What About Food Costs? Amber Waves 6(1):10-15.

Luthin, J. and R. Worstell, 1957. The Falling Water Table in Tile Drainage-A Laboratory Study. Soil Science Society of America Journal 21:58-584.

Parsons, D.F., M. Hayashi, and G. van der Kamp, 2004. Infiltration and Solute Transport under a Seasonal Wetland: Bromide Tracer Experiments in Saskatoon, Canada. Hydrological Processes 18:2011-2027.

Poiani, K. and W.C. Johnson, 1993. A Spatial Simulation Model of Hydrology and Vegetation Dynamics in Semipermanent Prairie Wetlands. Ecological Applications 3:279-293.

Poiani, K., W.C. Johnson, and T.G. Kittel, 1995. Sensitivity of a Prairie Wetland to Increased Temperature and Seasonal Precipitation Changes. Water Resources Bulletin 31:283-294.

Poiani, K., W.C. Johnson, G.A. Swanson, and T.C. Winer, 1996. Climate Change and Northern Prairie Wetlands: Simulations of Long-Term Dynamics. Limnology and Oceanography 41:871881. 
Prince, H., 1997. Wetlands of the American Midwest: A Historical Geography of Changing Attitudes. University of Chicago Press, 410 pp., ISBN-0 226682838.

Schwab, G.O., N.R. Fausey, and C.R. Weaver, 1975. Tile and Surface Drainage of Clay Soils: II. Corn, Oats and Soybean Yields (1962-1972). Res. Bull. No. 1081. Ohio Agricultural Research and Development Center, Ohio State University, Wooster.

Skagen, S.K., D.A. Granfors, and C.P. Melcher, 2008. On Determining the Significance of Ephemeral Continental Wetlands to North American Migratory Shorebirds. The Auk 125(1):2029.

Stewart, R.E. and H.A. Kantrud, 1978. Classification of Natural Ponds and Lakes in the Glaciated Prairie Region. Resource Publication 92, Bureau of Sport Fisheries and Wildlife, U.S. Fish and Wildlife Service, Washington, D.C.

Toksoz, S. and D. Kirkham, 1961. Graphical Solution and Interpretation of a New Drain-Spacing Formula. Journal of Geophysical Research 65:509-516.

U.S. Department of Agriculture, 2014. Crop Values: 2013 Summary. National Agricultural Statistics Service, Washington, D.C., ISSN:1949-0372.

van der Kamp, G. and M. Hayashi, 2009. Groundwater-Wetland Ecosystem Interaction in the Semiarid Glaciated Plains of North America. Hydrogeology 17:203-214.

van der Kamp, G., M. Hayashi, and D. Gallén, 2003. Comparing the Hydrology of Grassed and Cultivated Catchments in the Semi-Arid Canadian Prairies. Hydrological Processes 17:559575.

Van der Molen, W.H. and J. Wesseling, 1991. A Solution in Closed Form and a Series Solution to Replace the Tables for the Thickness of the Equivalent Layer in Hooghoudt's Drain Spacing Equation. Agricultural Water Management 19:1-16.

van der Valk, A.G., 2012. The Biology of Freshwater Wetlands. Oxford University Press, New York.

van der Valk, A.G. and R.L. Pederson, 2003. The SWANCC Decision and Its Implications for Prairie Potholes. Wetlands 23 (3):590-596.

Van Schilfgaarde, J., 1963. Design of Tile Drainage for Falling Water Tables. Journal of Irrigation and Drainage Division 89 (2): 1-13.

Voldseth, R.A., W.C. Johnson, T. Gilmanov, G.R. Gunenspergen, and B.V. Millet, 2007. Model Estimation of Land-Use Effects on Water Levels of Northern Prairie Wetlands. Ecological Applications 17:527-540.

Voldseth, R.A., W.C. Johnson, G.R. Guntenspergen, T. Gilmanov, and B.V. Millett, 2009. Adaptation of Farming Practices Could Buffer Effects of Climate Change on Northern Prairie Wetlands. Wetlands 29(2):635-647.

Walker, J., J.J. Rotella, S.E. Stephens, M.S. Lindberg, J.K. Ringelman, C. Hunter, and A.J. Smith, 2013. Time-Lagged Variation in Pond Density and Primary Productivity Affects Duck Nest Survival in the Prairie Pothole Region. Ecological Applications 23(5):1061-1074.

Werner, B.A., W.C. Johnson, and G.R. Guntenspergen, 2013. Evidence for 20th Century Climate Warming and Wetland Drying in the North American Prairie Pothole Region. Ecology and Evolution 3(10):3471-3482, DOI: 10.1002/ ece3.731.

Wright, C.K. and M.C. Wimberly, 2013. Recent Land Use Change in the Western Corn Belt Threatens Grasslands and Wetlands. Proceedings of the National Academy of Sciences 110(10):41344139, DOI: 10.107/pnas.1215404110.

Zedler, J.B., 2003. Wetlands at Your Service: Reducing Impacts of Agriculture at the Watershed Scale. Frontiers in Ecology and Environment 1:65-72.
Zedler, J.B. and S. Kercher, 2005. Wetland Resources: Status, Trends, Ecosystem Services, and Restorability. Annual Review of Environment and Resources 30:39-74. 